6- ORIGINAL ARTICLES

\title{
Copper-Zinc ratio and nutritional status in colorectal cancer patients during the perioperative period ${ }^{1}$
}

\author{
Sofia Miranda de Figueiredo RibeiroI, Amanda Maria Tomazini Munhoz Moya ${ }^{\mathrm{II}}$, Camila Bitu Moreno Braga ${ }^{\mathrm{II}}$, Fernanda \\ Aparecida Domenici ${ }^{\text {Vv }}$, Marley Ribeiro Feitosav ${ }^{\text {, Omar Feres }}{ }^{\text {VI, José Joaquim Ribeiro da Rocha }}{ }^{\text {VII }}$, Selma Freire de Carvalho da \\ Cunha ${ }^{\text {VIII }}$
}

DOI: http://dx.doi.org/10.1590/S0102-86502016001300006

IFellow PhD degree, Division of Medical Nutrition, Department of Internal Medicine, Ribeirão Preto Medical School, University of São Paulo, Brazil. Conception and design of the study, acquisition of data, manuscript writing, manuscript review.

IIGraduate Student, Ribeirão Preto Medical School, University of São Paulo, Brazil. Acquisition of data, manuscript writing, manuscript review.

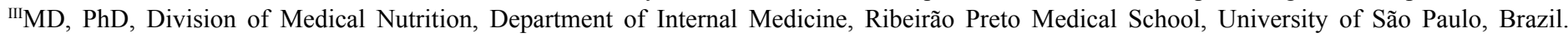
Acquisition of data, manuscript writing, manuscript review.

${ }^{\text {IV } M D, ~ P h D, ~ D i v i s i o n ~ o f ~ M e d i c a l ~ N u t r i t i o n, ~ D e p a r t m e n t ~ o f ~ I n t e r n a l ~ M e d i c i n e, ~ R i b e i r a ̃ o ~ P r e t o ~ M e d i c a l ~ S c h o o l, ~ U n i v e r s i t y ~ o f ~ S a ̃ o ~ P a u l o, ~ B r a z i l . ~}$ Acquisition of data, manuscript writing, manuscript review.

${ }^{\mathrm{v}} \mathrm{MD}$, Fellow PhD degree, Division of Coloproctology, Department of Surgery and Anatomy, Ribeirão Preto Medical School, University of São Paulo, Brazil. Manuscript review.

${ }^{V} \mathrm{PhD}$, Associate Professor, Department of Surgery and Anatomy, Ribeirão Preto Medical School, University of São Paulo, Brazil. Critical revising. VIIPhD, Associate Professor, Department of Surgery and Anatomy, Ribeirão Preto Medical School, University of São Paulo, Brazil. Critical revising.

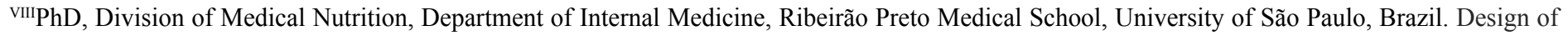
the study, acquisition of data, critical revising and final approval of the version to be published.

\begin{abstract}
PURPOSE: This study aimed to determine $\mathrm{Cu} / \mathrm{Zn}$ ratio, nutritional and inflammatory status in patients during the perioperative period for colorectal cancer.

METHODS: The study included patients with histological diagnosis of colorectal adenocarcinoma (Cancer Group, $\mathrm{n}=46$ ) and healthy volunteers (Control Group, $\mathrm{n}=28$ ). We determined habitual food intake, body composition, laboratory data of nutritional status, serum calprotectin and plasma $\mathrm{Cu}$ and $\mathrm{Zn}$ concentrations. Mann-Whitney U-test was performed between-group comparisons and Spearman correlation test for correlations between the variables.

RESULTS: Individuals in the Cancer Group presented significantly lower BMI, fat mass, plasma hemoglobin, total protein and albumin as compared with the Control Group. Serum calprotectin[70.1 ng/mL (CI95\% 55.8-84.5) vs.53.3 ng/mL (40.3-66.4), p=0.05], plasma $\mathrm{Cu}$ concentrations $[120 \mu \mathrm{g} / \mathrm{dL}(\mathrm{CI} 95 \%$ 114-126) vs. $106 \mu \mathrm{g} / \mathrm{dL}(\mathrm{CI} 95 \%$ 98-114), $\mathrm{p}<0.01]$ and the $\mathrm{Cu} / \mathrm{Zn}$ ratio [1.59 (CI95\% 1.48-1.71)vs. 1.35 (CI95\% 1.23-1.46), $\mathrm{p}=0.01$ ]were higher in patients with colorectal cancer than in controls. Additionally, the Cancer Group showed negative correlations between the $\mathrm{Cu} / \mathrm{Zn}$ ratio and $\mathrm{Zn}$ intake, hemoglobin, serum albumin, and positive correlation between the $\mathrm{Cu} / \mathrm{Zn}$ ratio and serum calprotectin.
\end{abstract}

CONCLUSION: These results indicate that an increased plasma $\mathrm{Cu} / \mathrm{Zn}$ ratio and serum calprotectin, and decreased protein values may be a result of the systemic inflammatory response to the tumor process.

Key words: Zinc. Cooper. Nutritional Status. Inflammation. Colorectal Cancer. 


\section{Introduction}

The trace elements zinc $(\mathrm{Zn})$ and copper $(\mathrm{Cu})$ are essential for human health. Dietary factors, including a wide range of phytate intakes, cellular location, cell-specific expression, and regulation of the transporters involved in enteric $\mathrm{Zn}$ absorption are important for bioavailability this mineral ${ }^{1}$. Approximately $70 \%$ of circulating $\mathrm{Zn}$ is bound to serum albumin ${ }^{2} . \mathrm{Zn}$ is a constituent of more than 300 enzymes involved in a broad spectrum of activities, including anti-inflammatory and antioxidant effects ${ }^{3}$ and genetic transcription regulation ${ }^{4}$. Dietary $\mathrm{Cu}$ is absorbed mainly in the duodenum and is chelated by metallothioneins in the cytoplasm of cells ${ }^{5} . \mathrm{Cu}$ binds to proteins involved in a variety of biological processes $^{6}$ such as the formation, maturation and stabilization of connective tissues and structure of the extracellular matrix ${ }^{7} \mathrm{Cu}$ is involved in the detoxification of reactive oxygen species as it binds to metallothioneins under reducing conditions and influences the activity of antioxidant enzymes ${ }^{6} . \mathrm{Cu}$ is also essential for the immune response, including the production ofIL-2 by activated lymphocytic cells ${ }^{7}$.

$\mathrm{The} \mathrm{Cu} / \mathrm{Zn}$ ratio has been correlated with nutritional status in institutionalized elderly ${ }^{8}$ and patients under peritoneal dialysis ${ }^{9}$. Also, this ratio is considered as a marker for asthma severity ${ }^{10}$ and prostate cancer detection ${ }^{11}$. In the elderly, increased $\mathrm{Cu} / \mathrm{Zn}$ ratio was a predictive factor of mortality and it was associated with reduced serum albumin and increased inflammatory markers, like C-reactive protein and erythrocytes sedimentation rate $^{12}$.

Calprotectin (S100A8/A9) accounts for more than $60 \%$ of total soluble proteins in the cytoplasm of neutrophils ${ }^{13}$. Serum calprotectin has been suggested as a biomarker of chronic inflammation ${ }^{14}$, and to be correlated with acute phase response markers' concentrations ${ }^{15}$. The release of calprotectin by activated leukocytes ${ }^{13}$ precedes the increase in liver protein synthesis in response to inflammatory stress ${ }^{13,15}$. In view of the detection of early acute inflammatory changes, the simultaneous determination of calprotectin and hepatic markers levels would be clinically useful for monitoring several inflammatory conditions ${ }^{15}$.

Colorectal cancer is one of the major causes of death by cancer in the western world, and surgery for excision of the primary tumor is undertaken in $80 \%$ of patients ${ }^{16}$. Preoperative colorectal cancer patients are not usually considered to be at risk of malnutrition ${ }^{16}$. Although these patients may be classified as overweight or obese according to the BMI, some of them have a weight loss greater than $10 \%$, indicating a certain degree of malnutrition ${ }^{16}$. So far, to our knowledge, there is no available study correlating nutritional status and inflammatory status with $\mathrm{Cu} / \mathrm{Zn}$ ratio in colorectal cancer. The present study aimed to compare and correlate the plasma $\mathrm{Cu} / \mathrm{Zn}$ ratio with nutritional and inflammatory status in colorectal cancer patients during the perioperative period.

\section{Methods}

The study was approved by the local Research Ethics Committee (Proc\#14102/2010) and data were collected between May 2011 and December 2012 in a Brazilian university hospital. Informed consent was obtained from all individual participants included in the study. A convenience sample of 46 patients (22 male), aged 65.8 years (62.0-69.7) in the perioperative period for stage II, III or IV adenocarcinoma of colon or medium/high rectum (Cancer Group) participated in the study. All patients had no previous chemotherapy or radiotherapy and were free of the recurrent neoplastic lesion. A group of 28 healthy volunteers (14 male), aged 61.4 years (58.1-64.8) (Control Group) was also included in the study. These volunteerswere recruited by a community program, and use of a local press and radio. Exclusion criteria included the history of neoplasms, autoimmune diseases, chronic inflammatory diseases, active infection, liver or kidney diseases, and use of supplements containing $\mathrm{Zn}$ and $\mathrm{Cu}$.

\section{Assessment of food intake and body composition}

At the beginning of the study, a semi-quantitative food frequency questionnaire (SQFFQ) was applied to evaluate subjects' habitual food intake in the preceding six months. Daily intake of nutrients was determined by using the software (NutWin, version 2.5a, UNIFESP, São Paulo, Brazil).

For anthropometry, height (m) and body weight $(\mathrm{kg})$ were measured using standardized techniques, and the Body Mass Index $\left(\mathrm{BMI}=\left[\right.\right.$ weight $/$ height $\left.\left.^{2}, \mathrm{~kg} / \mathrm{m}^{2}\right]\right)$ was calculated. Body composition was determined by bioelectrical impedance analysis (Biodynamics BIA 450 Analyzer, Biodynamics Corporation, Shoreline, WA, USA).

\section{Biochemical analyses}

Routine laboratory analyses included serum levels of total protein and albumin (colorimetry), determined with an automatic biochemical analyzer (Konelab 6.0, Winer, Argentina). Hemoglobin levels were determined by photometry, using the ABX Pentra DX120 (Horiba Ltd, Kyoto, Japan). Serum calprotectin (S100A8/A9, MRP8/14) was measured by ELISA (Multiskan FC Microplate Photometer, Thermo Scientific Uniscience) using 
a commercially available kit (DRG Diagnostics, EIA5111; Springfield, New Jersey, USA). The standard curve ranged from 3.9 to $250 \mathrm{ng} / \mathrm{mL}$. Plasma zinc and copper values were determined by flame atomic absorption spectrophotometry (Varian, model AA200, Melbourne, Australia), at a wavelength of $213.9 \mathrm{~nm}$ and $327.4 \mathrm{~nm}$, respectively. The normal values for plasma zinc and copper were set at $70-140 \mu \mathrm{g} / \mathrm{dL}$ and $50-120 \mu \mathrm{g} / \mathrm{dL}$, respectively.

\section{Statistical analysis}

Mann-Whitney U-test was used for comparisons between demographic and clinical features of groups, and the results are shown as geometric mean and $95 \%$ confidence interval. Spearman's correlation coefficient was used for correlation analyses between variables and the $\mathrm{Cu} / \mathrm{Zn}$ ratio. Data analyses were performed with
Statistica software (version 8.0; StatSoft Inc., Tulsa, OK, USA). The level of significance was set at $5 \%$.

\section{Results}

Food intake, body composition and laboratory data are shown in Table 1. Energy, protein and zinc intake was similar in the Cancer Group as compared with controls in the six months prior to the study. Individuals of the Cancer Group exhibited lower body weight, BMI and fat mass as compared with the Control Group. Colorectal cancer patients presented lower hemoglobin, total protein and albumin serum concentrations than controls. Plasma $\mathrm{Cu}$ concentrations were higher in patients with colorectal cancer than in controls, and plasma $\mathrm{Zn}$ was similar between groups. Hence, a higher $\mathrm{Cu} / \mathrm{Zn}$ ratio was found in the Cancer Group than in the Control Group.

TABLE 1 - Mean and IC 95\% of food intake, body composition and laboratory data of patients with colorectal cancer (Cancer Group) in the perioperative period and healthy volunteers (Control Group).

\begin{tabular}{|c|c|c|c|}
\hline & $\begin{array}{c}\text { Cancer Group } \\
(\mathrm{n}=46)\end{array}$ & $\begin{array}{c}\text { Control Group } \\
(\mathrm{n}=28)\end{array}$ & $P$-values \\
\hline \multicolumn{4}{|c|}{ Habitual food intake } \\
\hline Energy (kcal) & $1962(1774-2150)$ & $2113(1811-2416)$ & 0.36 \\
\hline Protein (g) & $67.7(59.1-76.4)$ & $82.9(65.8-100.1)$ & 0.15 \\
\hline Carbohydrate (g) & $253(222-284)$ & $283(235-331)$ & 0.21 \\
\hline Lipids (g) & $77.9(70.0-85.8)$ & $75.8(65.0-86.6)$ & 0.88 \\
\hline Zinc (mg) & $8.3(7.3-9.3)$ & $9.7(7.7-11.7)$ & 0.29 \\
\hline Copper (mg) & $1.24(1.03-1.46)$ & $1.42(1.16-1.68)$ & 0.09 \\
\hline \multicolumn{4}{|c|}{ Bodycomposition } \\
\hline Weight (kg) & $66.9(62.4-71.3)$ & $73.5(67.8-79.2)$ & 0.04 \\
\hline $\operatorname{BMI}\left(\mathrm{kg} / \mathrm{m}^{2}\right)$ & $25.2(23.8-26.6)$ & $28.2(26.6-29.7)$ & 0.01 \\
\hline Lean mass $(\mathrm{kg})$ & $46.4(43.2-49.7)$ & $48.1(43.3-52.9)$ & 0.59 \\
\hline Fat mass $(\mathrm{kg})$ & $19.8(17.2-22.3)$ & $25.4(22.3-28.5)$ & $<0.01$ \\
\hline \multicolumn{4}{|c|}{ Laboratory data } \\
\hline Hemoglobin (g/dL) & $11.4(10.8-11.9)$ & $14.3(13.7-14.9)$ & $<0.01$ \\
\hline Total protein $(\mathrm{g} / \mathrm{dL})$ & $6.3(6.1-6.5)$ & $6.9(6.7-7.1)$ & $<0.01$ \\
\hline Albumin (g/dL) & $3.8(3.6-3.9)$ & $4.2(4.2-4.3)$ & $<0.01$ \\
\hline Calprotectin (ng/mL) & $70.1(55.8-84.5)$ & $53.3(40.3-66.4)$ & 0.05 \\
\hline Copper $(\mu \mathrm{g} / \mathrm{dL})$ & $120(114-126)$ & $106(98-114)$ & $<0.01$ \\
\hline Zinc $(\mu \mathrm{g} / \mathrm{dL})$ & $77.7(73.3-82.1)$ & $80.0(75.9-84.1)$ & 0.50 \\
\hline Copper/Zinc & $1.59(1.48-1.71)$ & $1.35(1.23-1.46)$ & 0.01 \\
\hline \multicolumn{4}{|c|}{ Body mass index: BMI } \\
\hline
\end{tabular}

In the Cancer Group there was a weak negative correlation between $\mathrm{Cu} / \mathrm{Zn}$ ratio and $\mathrm{Zn}$ intake $(\mathrm{r}=-0.24)$, serum albumin $(\mathrm{r}=-0.37)$ and hemoglobin $(\mathrm{r}=-0.42)$, and a weak positive correlation between $\mathrm{Cu} / \mathrm{Zn}$ ratio and serum calprotectin $(\mathrm{r}=0.28)$.

\section{Discussion}

This study has found that patients with colorectal cancer presented lower body weight, BMI and fat mass compared 
to healthy volunteers. Besides, the Cancer Group had lower hemoglobin, total protein and albumin serum levels, and higher serum calprotectin, plasma $\mathrm{Cu}$ and $\mathrm{Cu} / \mathrm{Zn}$ ratio than controls.

The assessment of habitual food intake by the SQFFQ revealed that the nutrient intake in patients with colorectal cancer was similar than in healthy controls, including $\mathrm{Cu}$ and $\mathrm{Zn}$, met the Dietary Reference Intakes (DRI). This result is different from the study reported by Ravasco et al. (2004) ${ }^{17}$, which showed that patients in the perioperative period of head and neck, esophagus, stomach and colorectal tumor surgery had low nutrient intake as assessed by the 24-hour recall method. The discrepancy between results may be explained by differences in the methods used to estimate food consumption in these studies, although some studies show correlations between nutrient intakes measured by a frequency questionnaire and multiple 24-hour dietary recalls or diet records ${ }^{18}$.

Anthropometric data of patients were similar to those found in the literature ${ }^{19}$. The prevalence of nutritional disturbances in colorectal cancer patients depends on the definitions of nutritional risk and malnutrition adopted at the time of evaluation ${ }^{19,20}$. Some studies have demonstrated a high prevalence of overweight and obesity in these patients ${ }^{19}$, indicating little effect on nutritional status, differently from other advanced neoplasms in the gastrointestinal tract ${ }^{21}$. However, it is worth mentioning that BMI may continue within normal range even after weight loss. History of weight loss was evaluated by the Subjective Global Assessment (SGA), which showed that $35 \%$ of patients with colorectal cancer were moderately or severely malnourished or at nutritional risk ${ }^{20}$. On the other hand, the Malnutrition Screening Tool (MUST) and the Nutritional Risk Index (NRI) identified undernutrition in 44\% and $53 \%$ of colorectal cancer patients, respectively ${ }^{20}$.

In colorectal cancer, food intake is slightly affected with no digestive or absorptive disturbances, and intestinal obstruction occurs only in advanced cases of the disease. On the other hand, inflammatory pathways are constitutively active in most cancers ${ }^{21}$ and may lead to reductions in body protein levels, regardless of food intake. Although colorectal tumors trigger inflammatory stress responses, albumin levels are generally within normal range or slightly reduced ${ }^{22}$. In this context, increased calprotectin levels in our cancer patients indicate its possible role in inflammationassociated carcinogenesis ${ }^{14}$. This increase has been related to the persistent innate immune cell activation in many epithelial cancers $^{14}$ and detection of calprotectin-positive myeloid cells within the tumor stroma in colorectalcancer ${ }^{23}$.

Also, our findings regarding $\mathrm{Cu}$ plasma concentrations are in accordance with those observed in uterine cervical ${ }^{24}$ and gut cancer $^{25}$, reporting higher levels of $\mathrm{Cu}$ as compared with healthy volunteers. Incremental changes of inflammatory biomarkers have been associated with augmented plasma $\mathrm{Cu}^{26}$. Approximately $90-95 \%$ of the total circulating $\mathrm{Cu}$ are bound to ceruloplasmin ${ }^{7}$, whose concentrations are elevated in response to inflammation, infection and various chronic diseases ${ }^{6,7}$. During stress and trauma conditions, the proinflammatory cytokines IL-1 and IL-6 stimulate the synthesis of acute-phase reactive protein by the liver ${ }^{7}$, which may explain the increase in plasma $\mathrm{Cu}$ levels. $\mathrm{Zn}$ deficiency was not observed in our patients, different from previous studies that reported low $\mathrm{Zn}$ levels in uterine cervical ${ }^{24}$ and gut cancer ${ }^{25}$ patients.

A greater $\mathrm{Cu} / \mathrm{Zn}$ ratio occurred in our Cancer Group than in the Control Group, similarly to previous studies on uterine cervical cancer ${ }^{24}$. Tuberculosis patients had a high level of copper and copper/zinc ratio when compared to healthy controls, and the alteration was more pronounced in those coinfected with $\mathrm{HIV}^{27}$. $\mathrm{The} \mathrm{Cu} / \mathrm{Zn}$ ratio has been pointed out as a diagnosis and prognosis factor of inflammation in lymphoma and leukemia ${ }^{28}$, gastric ${ }^{29}$ and breast cancer ${ }^{30}$

A limitation of this study was the relatively small numbers of patients and controls, although the Cancer Group was homogeneous regarding tumor site and histological diagnosis. Despite small sample size, we found negative correlations between the $\mathrm{Cu} / \mathrm{Zn}$ ratio and the nutritional parameters in patients with cancer. In subjects under peritoneal dialysis, elevated $\mathrm{Cu} / \mathrm{Zn}$ levels were associated with undernutrition, increased oxidative stress, inflammation and deterioration of immune function ${ }^{9}$. The $\mathrm{Cu} / \mathrm{Zn}$ ratio increased proportionally with increasing levels of prostate specific antigen in patients with prostate cancer ${ }^{11}$, and correlated with lipid peroxidation markers in asthma patients ${ }^{10}$.

\section{Conclusion}

This study has shown that the $\mathrm{Cu} / \mathrm{Zn}$ ratio and the inflammatory marker calprotectin are increased, and protein levels decrease in patients with colorectal cancer. These findings suggest that the $\mathrm{Cu} / \mathrm{Zn}$ ratio may be an inflammatory-nutritional biomarker, resulting from the inflammatory response to the tumor process. Further work might investigate whether other immunological and inflammatory markers could affect trace element status and clinical progression in cancer patients.

\section{References}

1. Cousins RJ. Gastrointestinal factors influencing zinc absorption and homeostasis. Int J Vitam Nutr Res. 2010;80(4-5):243-8. PMID:21462106. 
2. King JC. Does zinc absorption reflect zinc status? Int J Vitam Nutr Res. 2010;80(4-5):300-6. PMID:21462113.

3. Prasad AS. Impact of the discovery of human zinc deficiency on health. J Trace Elem Med Biol. 2014;28(4):357-63.PMID:25260885.

4. Prasad AS. Discovery of human zinc deficiency: 50 years later. J Trace Elem Med Biol. 2012;26(2-3):66-9.PMID:22664333.

5. Thiele DJ. Integrating trace element metabolism from the cell to the whole organism. J Nutr. 2003;133(1):1579S-80S.PMID:12730470.

6. Hordyjewska A, Popiolek L, Kocot J. The many "faces" of copper in medicine and treatment. Biometals. 2014;27(4):611-21. PMID:24748564.

7. Tapiero H, Townsend DM, Tew KD. Trace elements in human physiology and pathology. Copper. Biomed Pharmacother. 2003;57(9):386-98.PMID:14652164.

8. Belbraouet S, Biaudet H, Tébi A, Chau N, Gray-Donald K, Debry G. Serum zinc and cooper status in hospitalized vs. Healthy elderly subjects. J Am Coll Nutr. 2007;26(6):650-4.PMID:18187429.

9. Guo $\mathrm{CH}$, Chen PC, Yeh MS, Hsiung DY, Wang CL. $\mathrm{Cu} / \mathrm{Zn}$ ratios are associated with nutritional status, oxidative stress, inflammation, and immune abnormalities in patients on peritoneal dialysis. Clin Biochem. 2011;44(4):275-80.PMID:21223959.

10. Guo CH, Liu PJ, Hsia S, Chuang CJ, Chen PC. Role of certain trace minerals in oxidative stress, inflammation, CD4/CD8 lymphocyte ratios and lung function in asthmatic patients. Ann Clin Biochem. 2011;48(4):344-51.PMID:21546427.

11. Adaramoye OA, Akinloye O, Olatunji IK. Trace elements and Vitamin E status in Nigerian patients with prostate cancer. Afr Health Sci. 2010;10(1):2-8.PMID:20811517.

12. Malavolta M, Giacconi R, Piacenza F, Santarelli L, Cipriano C, Costarelli L, Tesei S, Pierpaoli S, Basso A, Galeazzi R, Lattanzio F, Mocchegiani E. Plasma copper/zincratio: an inflammatory/ nutritional biomarker as predictor of all-cause mortality in elderly population. Biogerontology. 2010;11(3):309-19.PMID:19821050.

13. Isaksen $B$, Fagerhol MK. Calprotectin inhibits matrix metalloproteinases by sequestration of zinc. Mol Pathol. 2001;54(5):289-92.PMID:11577169.

14. Gebhardt C, Németh J, Angel P, Hess J. S100A8 and S100A9 in inflammation and cancer. Biochem Pharmacol. 2006;72(11):162231.PMID:16846592.

15. Ikemoto $\mathrm{M}$, Matsumoto $\mathrm{S}$, Egawa $\mathrm{H}$, Okitsu $\mathrm{T}$, Iwanaga $\mathrm{Y}$, Umemoto S, Itoh H, Murayama H, Fujita M. A case with transient increases in serum S100A8/A9 levels implying acute inflammatory responses after pancreatic islet transplantation. Ann Clin Biochem. 2007;44(6):570-2.PMID:17961315.

16. Burden ST, Hill J, Shaffer JL, Todd C. Nutritional status of preoperative colorectal cancer patients. J Hum Nutr Diet. 2010;23(4):402-7.PMID:20487172.

17. Ravasco P, Monteiro-Grullo I, Vidal PM, Camilo ME. Cancer: disease and nutrition are key determinants of patients' quality of life. Support Care Cancer. 2004;12(4):246-52.PMID:14997369.

18. Thompson FE, Byers T. Dietary assessment resource manual. J Nutr. 1994;124(11):2245S-317S.PMID:7965210.

19. Pelser C, Arem H, Pfeiffer RM, Elena JW, Alfano CM, Hollenbeck AR, Park Y. Prediagnostic lifestyle factors and survival after colon and rectal cancer diagnosis in the National Institutes of Health (NIH)-AARP Diet and Health Study. Cancer. 2014;120(10):1540-7. PMID:24591061.

20. Tu MY, Chien TW, Chou MT. Using nutritional screening tool to evaluate the nutritional status of patients with colorectal cancer. Nutr Cancer. 2012;64(2):323-30.PMID:22292458.

21. Sheng H, Shao J, Washington MK, DuBois RN. Prostaglandin E2 increases growth and motility of colorectal carcinoma cells. J Biol Chem. 2001;276(21):18075-81. PMID:11278548.
22. Lai CC, You JF, Yeh CY, Chen JS, Tang R, Wang JY, Chin CC. Low preoperative serum albumin in colon cancer: a risk factor for poor outcome. Int J Colorectal Dis. 2011;26(4):473-81.PMID:21190025.

23. Stulik J, Osterreicher J, Koupilova K, Knizek, Macela A, Bures J, Jandík P, Langr F, Dedic K, Jungblut PR. The analysis of S100A9 and S100A8 expression in matched sets of macroscopically normal colon mucosa and colorectal carcinoma: the S100A9 and S100A8 positive cells underlie and invade tumor mass. Electrophoresis. 1999;20(4-5):1047-54.PMID:10344284.

24. Cunzhi H, Jiexian J, Xianwen Z, Jingang G, Shumin Z, Lili D. Serum and tissue levels of six trace elements and copper/zinc ratio in patients with cervical cancer and uterine myoma. Biol Trace Elem Res. 2003;94(2):113-22.PMID:12958402.

25. Federico A, Iodice P, Federico P, Del Rio A, Mellone MC, Catalano G, Federico P. Effects of selenium and zinc supplementation on nutritional status in patients with cancer of digestive tract. Eur J Clin Nutr. 2001;55(4):293-7.PMID:11360134.

26. Bo S, Durazzo M, Gambino R, Berutti C, Milanesio N, Caropreso A, Gentile L, Cassader M, Cavallo-Perin P, Pagano G. Associations of dietary and serum copper with inflammation, oxidative stress, and metabolic variables in adults. J Nutr. 2008;138(2):305-10. PMID:18203896.

27. Kassu A, Yabutani T, Mahmud ZH, Mohammad A, Nguyen N, Huong BTM, Hailemariam G, Diro E, Ayele B, Wondmikun Y, Motonaka J, Ota F. Alterations in serum levels of trace elements in tuberculosis and HIV infections. Eur J Clin Nutr. 2006;60(5):580-6. PMID:16340948.

28. Rosas R, Poo JL, Montemayor A, Isoard F, Majluf A, Labardini J. Utility of the copper/zinc ratio in patients with lymphoma or acute or chronic leukemias. Rev Invest Clin. 1995;47(6):447-52. PMID:8850142.

29. Hua Dong-LU, Zhi-Qiang W, Yu-Rong P, Tian-Shu Z, Xi-Zhu X, Wang Tian-K. Comparison of serum $\mathrm{Zn}, \mathrm{Cu}$ and $\mathrm{Se}$ contents between healthy people and patients in high, middle and low incidence areas of gastric cancer of Fujian Province. World J Gastroenterol. 1999;5(1):84-6.PMID:11819396.

30. Kuo HW, Chen SF, Wu CC, Chen DR, Lee JH. Serum and tissue trace elements in patients with breast cancer in Taiwan. Biol Trace Elem Res. 2002; 89(1):1-11.PMID:12413046.

\section{Correspondence:}

Selma Freire de Carvalho da Cunha

Av. Bandeirantes, 3900 - Campus Universitário - Monte Alegre Departamento de Clínica Médica - Divisão de Nutrologia

14048-900 - Ribeirão Preto, São Paulo, Brasil

Tel.: (55 16) 3315-3369

sfreire@fmrp.usp.br

Conflict of interest: none

Financial source: Fundação de Amparo à Pesquisa do Estado de São Paulo (FAPESP), Brazil (Grant \# 2011/07867-4). Coordenação de Aperfeiçoamento de Pessoal de Nível Superior (CAPES), Brazil (Grant \# 35046878860).

${ }^{1}$ Research performed at Division of Nutrology (Department of Internal Medicine) and Division of Coloproctology (Department of Surgery and Anatomy), Ribeirão Preto Medical School, University of São Paulo, Ribeirão Preto-SP, Brazil. 